\title{
Knowledge to Teach and Knowledge for Teaching in Teacher Education Research
}

\author{
David Antonio da Costa ${ }^{1 *}$
}

${ }^{1}$ Federal University of Santa Catarina, Florianópolis / SC, BRAZIL
${ }^{\star}$ Corresponding Author: david.costa@ufsc.br

Citation: da Costa, D. A. (2020). Knowledge to Teach and Knowledge for Teaching in Teacher Education Research. Pedagogical Research, 5(3), em0059. https://doi.org/10.29333/pr/7936

\begin{tabular}{|c|c|}
\hline ARTICLE INFO & ABSTRACT \\
\hline Received: 25 Feb. 2020 & The article aims to present an excerpt from the research that investigates knowledge to teach arithmetic in \\
\hline Accepted: 3 Apr. 2020 & $\begin{array}{l}\text { practical classes in teacher training courses. More precisely, we are looking for traces of prescriptions of practices } \\
\text { at a knowledge systematization level that we seek to objectify in a set of articles from the journal A Eschola Publica } \\
\text { (1893-1894 and 1896-1897), which later became the book A Eschola Publica: ensaio de Pedagogia Prática, } \\
\text { published in } 1895 \text { by Typographia Paulista. In the late 19th century and early 20th century, Normal Schools in } \\
\text { Brazil had attached to them, what was called a Model School, which was designed to disseminate teaching } \\
\text { practices aligned with the renewal of the pedagogical methods and constituted the training model for teachers } \\
\text { who taught mathematics in early childhood education. In theoretical and methodological terms, this research is } \\
\text { based on Certeau's writing of the history (2010) and Chartier's cultural history (1990), considering Chervel's history } \\
\text { of the disciplines (1990) and Julia' school environment (2001). The analysis is based on the studies of the Swiss } \\
\text { Research Group on Social History of Education (ERHISE), which focused on socio-historical research on teacher } \\
\text { education. For Hofstetter \& Valente (2017), the objectified knowledge is that which is given to us as natural and } \\
\text { necessary, usually imposed by a group that starts to say the same thing, establishing a consensus. The analysis of } \\
\text { two articles from A Eschola Publica shows that knowledge for teaching is structured and incorporates the current } \\
\text { pedagogical vacancies in articulation with the knowledge to teach. }\end{array}$ \\
\hline
\end{tabular}

Keywords: history of mathematics education, teaching practices, knowledge for teaching, teacher training

\section{INTRODUCTION}

When thinking about professional training processes, in our case, the training processes of teachers who teach mathematics in early childhood education, Rey's studies (2006) help us to problematize their curricula. This author indicates as distinctive features of most professional training processes the institution of specific spaces for learning, which breaks the logic of mimicry in a situation. To problematize the integration of professional knowledge in a training curriculum, Rey considers [the curriculum].

[...] it is an organized, planned sequence of learning situations. This means that it [the curriculum] is designed according to a progression: it goes from easy to difficult, from simple to complex or in any other order inspired by a didactic model, but always according to the progressivity considered most favorable to learning. This progression is combined: the path to which the student will be restricted is instituted by one or more actors who are no longer just expert practitioners of what is to be learned, but who are responsible for establishing progressivity, controlling and implementing it (Rey, 2006, p. 84).

According to Rey (2006), human learning always takes forms that oscillates between two extremes poles called spontaneous learning and ordered learning by a curriculum. This ordered learning by a curriculum, also called didactic learning, determines that the practice to be learned must be analyzed in simpler elements that will be worked according to a pre-established order. Because of this, two different situations arise.

Firstly, the best order considered to learn the operations of a practice does not come close to the conditions of its effective exercise. And this is not only because the validation criteria for these practices but because the separation of learning time and practice in common social conditions goes along with a differentiation of status, since the apprentice has neither the responsibilities nor the prerogatives of the active professional (Rey, 2006).

Secondly, learning practice that is learnt exclusively by practice itself requires its decomposition, a form of explicitness, exteriorized and objectified. Learning does not operate by identifying the speech in action, but by differentiating the speech about action. This conclusion is fundamental to understand the schooling in professional training courses and their curricula, because 
these kind of social practices are converted into discourses and their transmission is made possible through those discourses (Rey, 2006).

The objectification, explanation and presentation of a professional practice in a curriculum are accompanied by its depersonalization. Theorized and professional practices made didactic become transmissible, reproducible, and teachable. This conversion of a practice into text replaces the situation (in action). In the curriculum, practice becomes an object to be studied and not a medium in which a given subject is inserted. In other words, knowledge is at the center of the discussion about training.

This article aims to illustrate the methodological path of the research developed in the post-doctoral research studies in 20182019 at the Federal University of São Paulo, under the supervision of Prof. Dr.Wagner Rodrigues Valente, entitled "OS SABERES PARA ENSINAR MATEMÁTICA: um estudo histórico-comparativo entre São Paulo e Santa Catarina - dos exercícios práticos de ensino ao estágio supervisionado (1890-1950)" (KNOWLEDGE TO TEACH MATHEMATICS: a historical-comparative study between São Paulo and Santa Catarina - from practical teaching exercises to the supervised training 1890-1950) and intends to characterize knowledge for teaching arithmetic at Model School in São Paulo, Brazil, early twentieth century, using as a privileged source some articles by Oscar Thompson published in the pedagogical journal A Eschola Publica (1893-1894 and 1896-1897), which later became the book A Eschola Publica: ensaio de Pedagogia Prática (A Eschola Publica: essay on Practical Pedagogy), published by Typographia Paulista in 1895. This text is structured as follows: a) Introduction - addresses historical aspects of practices and practicum in the training process and spaces; a bibliographic review about teacher education research; and the role of knowledge in teacher education; b) Characterization of the Model School and its role in the normal course (preparation school for early childhood education teachers) in times of intuitive pedagogic vacancy; c) Development of the analysis of the articles chosen, characterizing the knowledge to teach arithmetic and d) Final considerations.

\section{PRACTICES AND PRACTICUM IN THE TRAINING PROCESS AND SPACES}

The scenario of this research is São Paulo Normal School, an environment for the formation of teachers in the end of the $19^{\text {th }}$ century. The reform of the Public Instruction in São Paulo (1890), led by Caetano de Campos, changed the functioning of the Normal School. Teachers' education could no longer stick only to the encyclopedic and traditionalist theoretical principles, but it should be mainly practical, aimed at professional training in the search for quick and concrete results that were so necessary to the nation (Almeida, 1995).

By referral of Prof. Horace Lane, director of the American School, Caetano de Campos, in 1890, hires teachers Maria Guilhermina Loureiro de Andrade and Miss Márcia Priscilla Browne both educated in the United States, and very familiar with the new intuitive method of teaching. Each of them ran one of the sections of the Escola Modelo do Carmo (name given to the São Paulo Model School). After the first year of operation of Model School, in 1892, principal Maria Guilhermina Loureiro de Andrade requested the termination of her contract, leaving Miss Márcia Browne directing the two sections (Costa, 2010).

The school became the center that irradiated the intuitive method through the hands and enthusiasm of Caetano de Campos, aligned with the positivist thought according to which the physical-chemical and biological laws and the natural sciences were decisive in education, even for the training of future teachers. The solid basis of this training was based on practical teaching exercises carried out in the application classes, a place where teachers were trained in the technique of transmitting knowledge based on observation as the determining meaning for the construction of their own pedagogical practice.

\section{Research on Teacher Education}

There is much research from different perspectives dealing with the theme of teacher education. International meetings indicated some trends and pointed to their intensification since the 1980s in Brazil. Romanowski (2013) used the synthetized results from Work Groups at ANPEd (National Association of Graduate Studies and Research in Education) and ENDIPE (National Meeting of Didactics and Teaching Practice), together with other references that produced state-of-the-art results. Among the trends, the author highlights action, participatory and collaborative research groups, i.e., studies that place teachers as collaborators and researchers of their own practice. Considering the teachers' professional development, reflective research, life stories and training through research stand out.

Valente (2019) also lists the works carried out by Marli André on research tensions and perspectives on teacher training (André, 2011); as well as those produced by Bernadete Gatti on initial training for elementary school pre-service teachers (Gatti, 2014). Libânia Xavier's studies on the construction of the teaching profession (Xavier, 2014) and Itale Cericato's bibliographic review on the same theme (Cericato, 2016) compose an overview of educational research.

For research on the training of mathematics teachers, Valente (2019) highlights those carried out since 2002 by the Group of Oral History and Mathematics Education (GHOEM) in the elaboration of a (historical) mapping on the training and performance of teachers who teaches mathematics in Brazil (Garnica et al., 2011). It also indicates those carried out by the Group of Studies and Research on the Training of Mathematics Teachers (GEPFPM), disseminated through the publication of an e-book, "Mapeamento da pesquisa acadêmica brasileira sobre o professor que ensina matemática: período 2001-2012" (Mapping Brazilian academic research on the teacher who teaches mathematics: period 2001-2012) (Fiorentini et al., 2016).

The data collected indicate that the research works mostly mobilize knowledges of action, those that encompass the knowledges, the competences, the skills (or aptitudes) and the attitudes related to the knowledge, to the know-how and to the knowing how to be. The emphasis on subjectivity is highlighted in research and this subjectivity, in terms of knowledge, is expressed through the knowledges of action.

The conclusion is that there are research gaps in the initial teacher training. 


\section{The Role of Knowledges in Training}

It is necessary to differentiate two meanings of the word knowledge: the one that is associated with the semantic field of the incorporated knowledge related to the skills, know-how, competencies, aptitudes, attitudes, professionalities, and the one identified by the objectified knowledge, which, according to Barbier refers to:

the realities with the status of representations [...] giving rise to propositional statements and being the object of a social valorization sanctioned by a transmission-communication activity. They, those representations, consequently, have a distinct existence from those who enunciate them or those who appropriate them. They are conservable, accumulative, appropriable (Barbier, 2014, p. 9).

Hofstetter and Schneuwly (2017) point out that knowledge is part of the gear of education and training institutions. Thus, according to them, this kind of knowledge will be manifest in the form of an object and/or teaching instrument for teaching professionals. The focus of reflection in these studies (majorly of researches made by ERHISE group - Équipe de Recherche en Histoire Sociale de l'Éducation, from the University of Geneva, Switzerland) falls on the formalized knowledge that is associated with the objectified knowledge.

It is possible to define two theoretical categories of learning constituting the teaching profession: "the knowledge to teach, that is the object of their work; and the knowledge for teaching, in other words, the knowledges that are the tools of their work" (Hofstetter \& Schneuwly, 2017, p. 131).

The knowledge to teach is the teacher's object of work and is associated with the knowledge for teaching the students. This knowledge is directly linked to the educational institution that somehow defines what should or should not be taught. They are manifested mainly in teaching plans or programs/curricula, in student and teacher textbooks, in documents that provide prescriptions for teaching and other types of documents that systematize guidelines as to what should be taught.

For Hofstetter and Schneuwly (2017):

the choice of the knowledge and its transformation into knowledges to teach is the result of complex processes that fundamentally transform the knowledge in order to make it teachable. This process can even lead to the creation of knowledge that is specific to the educational institutions, necessary for them to take on their functions (p.133).

Supported by prescriptions and regulations, textbooks and other documents used in daily school life, we aim to identify initially what would be the "objects" of work of the primary school teacher regarding the math teaching. Beyond the content prescribed, we seek to look at the goals and purposes of those knowledges, to understand their choice and implementation.

On the other hand, knowledge for teaching are contents that are related to the objects of the work of teaching, teaching practices and the institutions that define teaching professional activity. As for the objects of the work of teaching, knowledge for teaching can be associated with the knowledge to teach and to the students (their own knowledge, their developments, ways of learning, etc.). As for teaching practices, the knowledge for teaching is associated with methods, procedures, devices, choices of knowledge to teach, organization and management modality. About the institutions, knowledges for teaching are associated with the lesson plans, the teaching instructions and prescriptions, the purposes of the educational institutions, the administrative and political structures that regulate and standardize the educational system etc.

\section{THE MODEL SCHOOL IN SÃO PAULO, THE TEACHING PRACTICE AND THE INTUITIVE METHOD - LATE 19TH AND EARLY 20TH CENTURY}

Conceived as an integral part of the Normal School, the Model School was the place where to intended to demonstrate didactic procedures, observation and teaching practice for third year students of the normal course and, finally, dissemination point of techniques based on the intuitive teaching method (Monarcha, 1999, p. 179).

The intuitive teaching method gained relevance at Model School. Teaching Practice as a discipline worked by those third year students of the normal course in the Model School was configured and advanced in the first decades of the 20th century. Between 1890 and 1920, many curricula were adopted at the Normal School, however, the Teaching Practice continued to be carried out.

Observing the work of a more experienced teacher at Model School was the basis of Teaching Practice. Hence, "the art of teaching becomes largely dependent on the ability to observe" (Carvalho, 2000, p. 226).

Fulfilling the logic centered on the reproduction of a school model, São Paulo public education system was organized during the first Republican decades. The devices used to produce visibility of the school practices are materialized in inspection reports, in pedagogical journals and publications fostered by the São Paulo Education Instruction Board.

Taking pedagogical journals as privileged sources for this investigation is based on the idea that periodical publications constitute "a space for affirming currents of actions and educational thought" (Borges, 2014, p. 246). Also, the press influences the "configuration of the educational field, the affirmation of teaching professionalization, the debate of pedagogical ideas and the expansion of educational and school practices" (Borges, 2014, p. 246).

A set of articles by Oscar Thompson published in the pedagogical journal A Eschola Publica (1893-1894 and 1896-1897) served as a source for research related to the arithmetic knowledge dealt with at Model School. Subsequently, this set of articles becomes a book as previously referenced. 
This same set of data was used by Oliveira (2018) to characterize the appropriations of the intuitive method by Oscar Thompson from his recommendations for teaching numbers and calculus. Such study allowed to characterize the order and the pace of the teaching of arithmetic carried out by Thompson following the psychological recommendations for teaching of arithmetic, that is, starting from the use of concrete objects and working more than one content simultaneously. Such option of work contradicts the logical order, that is, that which starts from the abstract and follows the successive order of knowledge (first teaching how to count, then adding, then subtracting, multiplying and dividing....).

The journal A Eschola Publica

emerged with an explicit purpose of meeting the needs of an educational system in the implementation phase, having as favorable aspects the originality of the initiative, the intellectual training of those who set out to edit it, the prestige and, consequently, the political support its editors enjoyed and the prominence raised by its educational practices even before the creation of the journal (Valdemarin \& Pinto, 2010, p. 170).

The interests of this investigation rest in the analysis of the processes and dynamics of the constitution of the professional knowledge of the teacher who teaches mathematics, considering the formalized knowledge - the objectified knowledge. Thus, the objective is to capture methods used, didactics, prioritized knowledge, pedagogical orientations, which are consolidated and become objectified knowledge unfolded in the knowledge for teaching and knowledge to teach in the training of the teacher who teaches mathematics.

\section{Knowledge for Teaching Arithmetic in the Guidelines of $A$ Eschola Publica}

The set of articles entitled "Arithmetica Elementar", by Oscar Thompson, published since the first issue of $A$ Eschola Publica, July 1893 and organized in eleven lessons, presents a series of prescriptions and guidelines for arithmetic teaching. To exemplify the analysis about the knowledge for teaching arithmetic, we present the analysis of the first two lessons that deal with both counting and first numbers. In the preamble of the first of the articles published under the title "Arithmetica Elementar", which reports the pace the teacher should take when conducting a class, it is possible to understand the tone that the São Paulo reformers outlined for practical arithmetic classes.

In the past, young children were meant to, since they entered school, to memorize figures and tables, work that was not enjoyable in any way and tired their memories.

Today, every effort is made to make teaching of such subject attractive so that it leads the child to show interest in it from the first lessons.

And the best way to obtain this desideratum is to carry out the study of numbers.

The child must not consider the figures as mere symbols, but as groups of objects.

Only then adding, for example, four and three, the result, seven, will not be an effort of verbal memory, but an act of inner perception; because the child thinks, he/she understands that the result - seven, has a group of four objects and another group of three objects.

Many difficulties arise regarding the teaching of this subject, but all these difficulties will disappear if the teacher presents objects, tablets or figures to the children.

In this way, the study becomes pleasant not only for the master but also for the students.

The first lessons will not exceed the number ten, and will consist of analyzing the numbers (Thompson, 1895, p. 29-30).

Class preparation was also covered in the article even before starting details on the first and second lessons. This preparation is thoroughly described so that the teacher can appropriate it.

Let pupils stand around a table.

In the middle of the table, tablets one decimeter long and two centimeters wide, figurines and other objects.

The teacher, too, will remain standing, near one end of the table.

Thus, the class will be prepared for the lesson (Thompson, 1895, p. 30).

Such guidelines, written by Thompson and aimed at the circulation of the pedagogical journal, crystallize knowledge for teaching arithmetic that primary school teachers should appropriate in their task. In other words, it was of paramount importance that teachers know how to teach through objects: and for that, the disposition of students and teachers to properly mobilize objects was essential.

The first two lessons present examples of dialogues between teacher and student. Each student will repeat the same action, showing the object, being demanded to complete sentences with well-spoken words. The first lesson will take place with the manipulation of a single object and the questions will serve to teach the child to count, add, subtract, multiply and divide. The 
second lesson will follow the same idea, with the manipulation of two objects. In the end, the child should be able to tell the "story of number two". Example: "One and one equals two. One out of two equals one. Two out of two equals none. One two equals two. Two ones equals two. Two has two ones. Two has one two" (Thompson et al., 1895, p. 32).

The analysis by Oliveira (2018) contribute to reinterpretate these sources. The first two lessons recorded in the inaugural article of $A$ Eschola Publica show the first movements of the intuitive teaching of arithmetic knowledge that would occur through two teaching processes: by handling the concrete object (on the part of the student) and by orality, that is, by the process promoted by teacher-student dialogue based on concrete object. "Conversation is a kind of game that is configured between questions and answers" (Oliveira, 2018, p. 57). From the knowledge to teach an intuitive arithmetic, a knowledge for teaching is articulated in the actions that the teacher performs as the teacher-student dialogue is promoted. This assertion is in line with the proposition of Hofstetter and Schneuwly (2017): knowledge to teach is articulated with knowledge for teaching.

Therefore, making the child learn to count and calculate is to have concrete objects within its reach, and then to practice a dialogue. The organization and spatial arrangements of objects that favor students' learning are configured as ingredients of knowledge for teaching that the future teachers must mobilize in their professional work.

The second part of the sequence of Thompson's articles (Thompson et al., 1895, p. 33) sheds light on the need for the teacher to give some written exercises, which must begin with the figures 1 to 9. Thompson's guidelines are for the teacher to address the class with the materials and question the students about the quantities and record on the blackboard the figures corresponding to those quantities.

\author{
Hold a tablet and ask the children: \\ -How many tablets do I have? \\ -You have a tablet. \\ Go to the blackboard, hold the chalk and tell them: \\ -One tablet is written like this, - 1 - \\ Hold a pencil and ask them: \\ -How many pencils do I have? \\ -You have one pencil.
}

-Where did I write the number 1 ?

-Who can show it on the blackboard?

NOTE: The questions should always be addressed to the class and when the children show they are eager to answer, the teacher will then call one of them. In this way, children will follow the teacher's explanations with great care and interest (Thompson et al., 1895, p. 33).

Oliveira (2018), in his detailed analysis indicates that, unlike previous lessons, there are changes in the student's role: instead of handling objects and speaking, the student must now observe and write. Students remain in contact with the concrete items, not using the hand, but the vision. Thus, teaching favors observation as opposed to the handling of concrete objects, favoring students' contact with the writing of figures $[1,2,3, \ldots, 9]$.

Upon reaching number 9 , the lesson goes on to study the "zero".

Let us now teach children to read and write the number - 0 .

Raise your arm and ask them:

-What do I have in my hand?

- You have nothing in your hand.

-Well, nothing is also written like this - 0 .

-Read what the chalk did on the blackboard.

-Nothing.

Hold the pencil and write this number (Thompson et al., 1895, p. 34).

Oliveira's study (2018) for this part identifies a significant change: the digit "0" being anticipated by the word nothing. Technically, the intention is to inform that from the concrete study of the number, the term nothing represents the number " 0 ". If 
the order of treatment of arithmetic was the logic of the contents, the approach would be to present this number as zero. In short, when teaching arithmetic by its abstract part, that is, by the logic of the contents, 0 is zero; when the psychological teaching of arithmetic is taken, that is, when it is taught in concrete, 0 is nothing.

In this way, the knowledge for teaching is based on the understanding of the method that imposes the change of the student's role: the teacher takes on the role of presenting the quantities and relating them to the recording of the figures made on the blackboard. That action of the teacher in showing the quantities is linked to a knowledge to teach: the writing of the figures [1, 2, $3, \ldots, 0]$.

\section{FINAL CONSIDERATIONS}

The analysis of Oscar Thompson's prescriptions, presented in the articles published in A Eschola Publica, allows us to appropriate the ideology for the teaching of arithmetic in the late 19th century and early 20th century at São Paulo Model School. The mobilization of the analytical categories of knowledge to teach and knowledge for teaching from the theoretical framework of Hofstetter and Schneuwly (2017) helps us to understand the intertwining of these two kinds of knowledge and characterize them better in their roles in educational and training institutions.

In the example explored in this article, knowledge for teaching arithmetic in Thompson's times is aligned with the intuitive pedagogical wave. There is the configuration of an intuitive arithmetic, that is, knowledge to teach that is not subordinated to mathematical logic, but to the logic of teaching. Such examples show that arithmetic is not taken as an invariant in teaching. There are different types of knowledge to teach that, in turn, are related to other types of knowledge for teaching at each time.

Expanding historical investigations of this nature subsidize and enhance the study of practices in initial teacher training courses, in our case, the initial training of teachers who teach mathematics.

\section{REFERENCES}

Almeida, J. S. (1995). Currículos da Escola Normal Paulista (1846-1920): revendo uma trajetória. Revista Brasileira Estudos Pedagógicos. Brasília, 76(184), 665-689. https://doi.org/10.24109/2176-6681.rbep.76i184.1106

André, M. (2011). Pesquisas sobre formação de professores: tensões e perspectivas do campo, in H. A. Fontoura e M. Silva, (org.). Formação de professores, culturas: desafios à Pós-graduação em Educação em suas múltiplas dimensões (pp. 24-36) E-book online. In: Encontro De Pesquisa em Educação da Região Sudeste, 10. Anped Sudeste. Retrieved from https://www.yumpu.com/s/OwxzdgvXT39ks6rl

Barbier, J.-M. (2014). Savoirs théoriques et savoirs d'action. Paris: PUF [1996].

Borges, R. A. S. (2014). Revistas pedagógicas: fontes para a pesquisa em história da educação matemática, in W. R. Valente, (Org.). História da educação matemática no Brasil: Problemáticas de pesquisa, fontes, referências teórico-metodológicos e histórias elaboradas. (pp. 246-258). São Paulo: Livraria da Física.

Carvalho, M. M. C. (2000). Reformas da instrução pública, in E. M. T. Lopes et. al. (Orgs.). 500 anos de educação no Brasil (pp. 225252, 2 ed.). Belo Horizonte: Autêntica.

Cericato, I. L. (2016). A profissão docente em análise no Brasil: uma revisão bibliográfica. Rev. Bras. Estud. Pedagog. [online], 97(246), 273-289. https://doi.org/10.1590/S2176-6681/373714647

Certeau, M. de. (2010). A escrita da história. 2. ed. Rio de Janeiro: Forense Universitária. Trad. Maria de Lourdes Menezes.

Chartier, R. (1990). A história cultural entre práticas e representações. Rio de Janeiro: Bertrand Brasil. Trad. Maria Manuela Galhardo.

Chervel, A. (1990). História das disciplinas escolares: reflexões sobre um campo de pesquisa. Teoria \& Educação. Porto Alegre, 2 , 177-229.

Costa. D. A. (2010). A Aritmética Escolar no ensino primário brasileiro: 1890-1946. (Ph. D. Thesis in Mathematics Education). Pontifícia Universidade Católica of São Paulo. São Paulo. Retrieved from https://repositorio.ufsc.br/handle/123456789/1792

Fiorentini, D., et al (org.). (2016). Mapeamento da pesquisa acadêmica brasileira sobre o professor que ensina matemática: período 2001-2012. Campinas: FE/Unicamp. Retrieved from https://www.fe.unicamp.br/pf-fe/pf/subportais/biblioteca/fev-2017/ebook-mapeamento-pesquisa-pem.pdf

Garnica, A. V. M., et al. (2011). Entre a amnésia e a vontade de nada esquecer: notas sobre Regimes de Historicidade e História Oral. Bolema, 25(4), 213-250. Retrieved from http://www.redalyc.org/pdf/2912/291223514011.pdf

Gatti, B. A. (2014). Formação inicial de professores para a educação básica: pesquisas e políticas educacionais. Est. Aval. Educ., São Paulo, 25(57), 24-54. https://doi.org/10.18222/eae255720142823

Hofstetter, R., \& Schneuwly, B. (2017). Saberes: um tema central para as profissões do ensino e da formação. In R. Hofstetter \& W.R. Valente (Org.). Saberes em (trans) formação: tema central a formação de professores (pp. 113-172, 1 ed.). São Paulo: Editora da Física.

Hofstetter, R., \& Valente, W. R. (2017). Saberes em (trans) formação: tema central a formação de professores. 1 ed. São Paulo: Editora da Física. 
Julia, D. (2001). A. cultura escolar como objeto histórico. Revista Brasileira de História da Educação. Campinas, 1, 9-43. Retrieved from http://periodicos.uem.br/ojs/index.php/rbhe/article/view/38749/20279

Monarcha, C. (1999). Escola normal da praça: o lado noturno das luzes. Campinas, SP: Editora da Unicamp.

Oliveira, M. A. (2018). Circulação, in: W. R. Valente. Cadernos de Trabalho II. São Paulo: Editora Livraria da Física.

Rey, B. (2006). Les compétences professionnelles et le curriculum: des réalités conciliables?, In Y. Lenoir \& M. -H. Bouillier-Oudot, Savoirs professionnels et curriculum de formation. (pp. 83-108). Laval: PUF.

Romanowski, J. P. (2013). Tendências da pesquisa em formação de professores. Atos de pesquisa em educação - PPGE/ME, 8(2), 479-499. https://doi.org/10.7867/1809-0354.2013v8n2p479-499

Thompson, O., et al. (1895). A Eschola Publica: ensaio de Pedagogia Prática. São Paulo: Typographia Paulista.

Valdemarin, V. T., \& Pinto, A. A. (2010). Das formas de ensinar e conhecer o mundo: lições de coisas e método de ensino intuitivo na imprensa periódica educacional do século XIX. Revista Educação em Questão. Natal, 39(25), 163-187. Retrieved from https://periodicos.ufrn.br/educacaoemquestao/article/view/4018/3285

Valente, W. R. (2019). Saber objetivado e formação de professores: reflexões pedagógico-epistemológicas. História da Educação, 23, e77747. Epub March 28. https://doi.org/10.1590/2236-3459/77747

Xavier, L. N. (2014). A construção social e histórica da profissão docente uma síntese necessária, Revista Brasileira de Educação, 19(59), 827-849. https://doi.org/10.1590/S1413-24782014000900002 